\title{
Czy można uczyć się choroby? Autorski program edukacji dorosłych w Akademii Walki z Rakiem
}

\author{
Is it possible to learn an illness? A proprietary education \\ program for adults in Academy for Fighting Cancer
}

Streszczenie. Poczucie niedoinformowania w przebiegu choroby nowotworowej powoduje wzrost lęku i depresji. Doświadczenia kliniczne wskazują, że dobrze poinformowani pacjenci są mniej obciążeni poczuciem bezsilności oraz niepewności. W Akademia Walki z Rakiem (AWzR) w Toruniu został opracowany i od 2005 roku jest realizowany autorski program edukacji dorosłych z chorobą nowotworową, którego celem jest pomoc w radzeniu sobie z emocjami, ich odreagowaniu oraz prowadzenie warsztatów umiejętności interpersonalnych, które chory/rodzina mogliby wykorzystywać w procesie zdrowienia czy podczas leczenia. W chwili obecnej program realizowany jest w 12 miastach w Polsce. Artykuł przedstawia założenia tego autorskiego programu.

Słowa klucze: choroba nowotworowa, edukacja, osoby dorosłe, radzenie sobie z chorobą

Summary. The feeling of being under-informed in the course of cancer causes an increase in anxiety and depression. Clinical experiments indicate that well-informed patients are less burdened by a feeling of helplessness and uncertainty. The Academy for Fighting Cancer (Akademia Walki z Rakiem - AWzR) in Torun has developed and since 2005 is conducting a proprietary education program for adults suffering from cancer with the goal of helping to deal with emotions, finding release, and conducting interpersonal skills workshops which would be useful for the patient/family in the process of recovery or during treatment. Currently, the program is conducted in 12 cities in Poland. This article presents its primary objectives.

Keywords: cancer, education, adults, dealing with illness 


\section{Wprowadzenie}

Choroba nowotworowa jest dramatycznym wydarzeniem życiowym niosącym ze sobą przewlekłe obciążenia, reakcje stresową, dolegliwości somatyczne. Osoby zmagające się z chorobami przewlekłymi są kimś więcej niż tylko "chorymi przewlekle”. W ich codziennym życiu niezmiernie ważne jest nie tylko to, jak chorzy postrzegają siebie i środowisko, ale jak są oni przez środowisko postrzegani. Negatywny wpływ na jakość życia chorych przewlekle ma niewątpliwie:

- istnienie norm społecznych w odniesieniu do zdrowia, odnoszących się do oczekiwania, że każdy musi cieszyć się dobrym zdrowiem,

- społeczne oczekiwanie, że wraz z postępem medycyny choroby przewlekłe powinny przestać istnieć,

- brak wsparcia dla chorych przewlekle w pokonywaniu przez nich lęków, izolacji społecznej,

- brak zdolności systemu ochrony zdrowia do reagowania adekwatnie do tej sytuacji (de Walden-Gałuszko, 2013, s. 23-30).

Większość pacjentów wyraża pragnienie uzyskania szczegółowych informacji o chorobie oraz o zaplanowanych badaniach diagnostycznych, leczeniu. Poczucie niedoinformowania powoduje wzrost lęku i depresji. Doświadczenia kliniczne wskazują, że dobrze poinformowani pacjenci są mniej obciążeni poczuciem bezsilności oraz niepewności. Wśród postaw chorych wobec informacji o chorobie możemy wyróżnić następujące:

- poszukującą - charakterystyczną dla osób poszukujących informacji o zagrożeniach (tzw. „czujni obserwatorzy”) - u tych osób zdobycie informacji o zagrożeniach wpływa na zmniejszenie niepewności i lęku,

- unikającą - charakterystyczną dla osób unikających informacji o zagrożeniach (tzw. „wytłumiacze ostrzeżeń") - osoby te dobrze tolerują niepewność, a pojawiające się informacje na temat przyszłych, niepomyślnych wydarzeń wzmagają lęk (Heszen-Niejodek, 1991, s.13-26).

Wyniki badań empirycznych wykazują, że wymiary poszukiwania i unikania informacji są niezależne i należałoby właściwie wyróżnić nie dwa, ale cztery style radzenia sobie (za: Gwozdecka, 2000, s. 85):

- styl charakteryzujący się wysokim poziomem poszukiwania informacji, przy niskim poziomie unikania informacji, 
- $\quad$ styl preferujący silne unikanie, przy mało intensywnym poszukiwaniu informacji,

- styl oparty na wysokim poziomie zarówno poszukiwania, jak i unikania informacji,

- $\quad$ styl charakteryzujący się małą skłonnością i do poszukiwania, i do unikania informacji.

Wymienione postawy należy uwzględniać przy planowaniu edukacji osób zmagających się z chorobą przewlekłą.

W literaturze można znaleźć pogląd, że interwencja edukacyjna nie powoduje dużego przyrostu wiedzy i w niewielkim stopniu przyczynia się do poprawy jakości życia pacjentów (por. Hundertmark-Mayser, 2004). Jednak $\mathrm{w}$ jednym $\mathrm{z}$ ostatnich przeglądów badań przeanalizowano 22 metaanalizy i 53 zrandomizowane badania, pokazując, że psychoedukacja ma pozytywny wpływ na zmaganie się z chorobą nowotworową i poprawę jakości życia, co pokrywa się z doświadczeniami praktycznymi. Pozytywne oddziaływanie szczególnie widoczne jest w obszarze samopoczucia emocjonalnego i wiedzy o chorobie (Laff, 2004, s. 168).

\section{Istota edukacji w chorobie nowotworowej}

W edukowaniu na rzecz zdrowia można wyróżnić trzy zasadnicze podejścia: promocyjne, profilaktyczne i terapeutyczne. W pierwszym z nich, edukacja zdrowotna ukierunkowana jest na zdrowie pozytywne i można ją definiować jako działania świadome i dobrowolne, prowadzące do stworzenia sposobności uczenia się zachowań, które sprzyjają zdrowiu lub modyfikowaniu dotychczasowych zachowań (Charońska, 1997, s. 24). Drugie podejście edukacyjne związane jest ściśle z profilaktyką chorób. Tu punktem wyjścia jest zdrowie negatywne, a celem tak rozumianej edukacji jest uniknięcie zachorowania lub przeciwdziałanie jego odległym skutkom (Woynarowska, 2007, s. 128). Podejście terapeutyczne (edukacja terapeutyczna, edukacja pacjenta) „powinna umożliwić pacjentom nabycie i utrzymanie zdolności, która pozwoli im kierować własnym życiem w sytuacji choroby. Jest to proces ciągły, zintegrowany z opieką medyczną. Edukacja terapeutyczna skoncentrowana jest na pacjencie. Zawiera ona: rozwijanie świadomości, autoedukację i psychospołeczne wsparcie uwzględniające stan choroby, zalecenia stosowania leków lub innych zabiegów terapeutycznych, działania opiekuńcze (...). Edukacja terapeutyczna zakłada pomoc pacjentom i ich rodzinom w rozumieniu choroby i terapii, rozwinięcie współpracy z pracownikami ochrony 
zdrowia, która umożliwi zdrowsze życie i utrzymanie lub udoskonalenie jakości życia" (Cylkowska-Nowak, 2008, s. 13-16). Podejście terapeutyczne powinno być zorientowane na pacjenta, czyli charakteryzować się:

- partnerskim traktowaniem,

- respektowaniem wartości, preferencji i potrzeb pacjenta,

- uwzględnianiem kontekstu społeczno-ekonomicznego chorego,

- wspólnym określaniem celów,

- angażowaniem jednostki w proces podejmowania decyzji,

- wyzwalaniem odpowiedzialności za własne zdrowie,

- szeroką, rzetelną informacją,

- wsparciem emocjonalnym,

- angażowaniem rodziny pacjenta,

- łagodzeniem lęku, strachu (Hejwosz, 2008, s. 205-207).

W psychoonkologii odpowiednikiem edukacji terapeutycznej jest psychoedukacja. Jej celem jest podnoszenie świadomości pacjentów i ich rodzin w różnych obszarach - do głównych należą:

- źródła choroby, sposoby jej leczenia i możliwości radzenia sobie ze skutkami ubocznymi terapii,

- $\quad$ sposoby redukcji przeżywanego stresu, rozpoznawanie i nazywanie własnych emocji, umiejętne wyrażanie uczuć,

- reedukacja obaw i niepokoju,

- sposoby doskonalenia się w prowadzeniu dialogu z lekarzami,

- budowanie systemu wsparcia (Swaminath, 2009, s. 171).

Uściślając, psychoedukacja przeznaczona jest dla osób chorych oraz ich rodzin i przyjaciół. Polega na edukowaniu wszystkich, którzy są zainteresowani i czują się gotowi, by pogłębić wiedzę o chorobie i możliwościach jej leczenia. Poszerzanie wiedzy, to nie tylko zdobywanie potrzebnego minimum wiadomości z zakresu medycyny, ale również nauka rozpoznawania własnych emocji. Nazywanie swych uczuć i umiejętne ich wyrażanie jest podstawą łagodzenia przeżywanego w chorobie stresu. Psychoedukacja jest także sposobnością, by w bezpiecznych warunkach pacjenci i ich bliscy doskonalili porozumiewanie się z personelem medycznym. Istotną częścią psychoedukacji jest również udzielanie rzetelnych informacji w zakresie socjalno-prawnym i zawodowym. Tym obszarem zajmują się profesjonalnie pracownicy socjalni. Do ich zadań należy m.in. poradnictwo dotyczące orzecznictwa rentowego, orzecznictwa o stopniu niepełnosprawności oraz zasiłków i świadczeń z pomocy społecznej (Colom, 2011, s. 338-340).

Edukacja terapeutyczna, psychoedukacja jest przykładem edukacji nieformalnej, czyli zorganizowanej formy aktywności edukacyjnej, odbywają- 
cej się poza formalnym systemem instytucji oświatowych (Hejwosz, 2008, s. 84). Charakteryzując edukację nieformalną należy powiedzieć, że:

- udział w niej jest dobrowolny i nastawiona jest na rozwój osobisty, doświadczenia życiowe, potrzeby i zainteresowania uczestników,

- cele tworzone są wraz z osobą, zakładają zmianę, kładą nacisk na poprawę; respektują potrzeby jednostki,

- nastawiona jest na aktywność, oparta jest na doświadczeniach życiowych, a stosowane metody oparte są na obserwacji, eksperymencie, doświadczeniu, refleksji,

- rola nauczającego jest minimalna, uczący sam siebie ocenia, zaś ocena efektów jest głównie werbalna i polega na samokontroli (tamże, s. 85).

W odniesieniu do osób chorych przewlekle, celem nadrzędnym edukacji terapeutycznej jest ułatwienie zmiany zachowań, poprawa stanu zdrowia, powrót do sprawności, samodzielnego radzenia sobie.

\section{Planowanie edukacji terapeutycznej w chorobie przewlekłej i jej znaczenie}

W planowaniu edukacji terapeutycznej osób chorych onkologicznie należy dążyć do uzyskania danych na temat ciężkości choroby i stopnia nasilenia objawów psychosomatycznych, wielkości zasobów osobistych oraz środowiska społecznego, motywacji do uczestniczenia w zajęciach edukacyjnych. Analizując to, jak choroba wpływa na życie pacjenta, warto zwrócić uwagę m.in. na następujące trudności i objawy psychiczne:

- fizyczne ograniczenia funkcjonowania, problem bólu,

- trudności związane $\mathrm{z}$ podejmowaniem metod diagnostycznych i leczniczych,

- ograniczenia w codziennej aktywności pacjenta,

- poczucie naruszenia własnej wartości, planów życiowych,

- problemy emocjonalne (depresja, lęk, gniew, wstyd),

- objawy wegetatywne, problemy behawioralne, zaburzenia poznawcze,

- problemy w relacjach międzyludzkich (Rogiewicz, Lutostańska, 2012, s. 24-52).

Diagnozując zasoby osobiste i środowiskowe osoby chorej na raka szczególną uwagę należy zwrócić na to, jak dalece zaakceptowała ona swoją chorobę, czy przejawia zachowania dysfunkcjonalne takie jak: bierność, 
poddanie się, bagatelizowanie, jaka jest siła jej ego. Ten ostatni, szczególnie istotny czynnik, pozwala przetrwać kryzysy życiowe i obejmuje:

- umiejętność postrzegania siebie i innych,

- umiejętność regulowania własnych uczuć, poczucia własnej wartości, emocji,

- umiejętność komunikacji wewnętrznej (dialog wewnętrzne), jak i zewnętrznej (komunikacja z innymi ludźmi),

- zdolność do przywiązania się do obiektów wewnętrznych i zewnętrznych; (Pouget-Schors, 2011, s. 38).

Obok powyżej wymienionych, niezwykle ważne jest postrzeganie i zdolność do uczenia się.

Realizacja edukacji terapeutycznej powinna umożliwić każdemu człowiekowi nabywanie kompetencji do świadomego działania na rzecz zdrowia. Przyjąć należy, że przewlekle chory człowiek dysponuje znacznym potencjałem zdrowotnym i że ten potencjał powinien być pobudzany, umacniany, promowany. Niezależnie od poziomu sprawności osoba chora przewlekle nastawiona jest na rozwiązywanie problemów zdrowotnych, poszukuje skutecznych metod i technik odzyskania zdrowia, reaguje na sygnały płynące z ciała, umie odczytywać własne potrzeby zdrowotne i je zaspokajać, wykazuje refleksję $\mathrm{w}$ odniesieniu do własnych przekonań zdrowotnych, wielokrotnie przekracza mity czy stereotypy dotyczące zdrowia i ciała (Zalewska-Meler, 2009, s. 47-48). Według U. Mehl, tematyka edukacji terapeutycznej powinna obejmować analizę zależności między chorobą a stresem, identyfikację niekorzystnych strategii radzenia sobie $z$ chorobą, strategie samokontroli, które pozwalają wzmocnić poczucie decydowania o sobie, wspieranie korzystnej komunikacji, satysfakcjonujących relacji z osobami bliskimi oraz aspekty społeczno-prawne i zawodowe (2011, s. 348).

Należy pamiętać, że pacjenci z rakiem, po wyjściu z gabinetu lekarskiego zapominają aż $60 \%$ przekazanych im informacji, co jest spowodowane ich silnym, emocjonalnym wzburzeniem, poczuciem niepokoju. Asymilacji wiedzy sprzyja bezpieczna atmosfera i dlatego psychoedukacja, mająca na celu wzmocnienie stabilizacji emocjonalnej, zwiększa możliwość odbierania i przetwarzania informacji. Korzystnym okresem dla uczestnictwa w grupach psychoedukacyjnych jest faza stawiania diagnozy i pierwszy okres leczenia. Dla niektórych pacjentów jest to jednak okres po zakończeniu terapii lub okres rehabilitacji, ponieważ dopiero na tym etapie choroby są w stanie przyjmować nowe informacje. Edukacji terapeutycznej sprzyja zamknięta grupa psychoedukacyjna (od początku do końca w grupie są ci sami chorzy), 
ponieważ w tych warunkach wytwarza się atmosfera zaufania i przynależności (kohezja grupy) (tamże, s. 347).

Psychoedukacja może być stosowana podczas indywidualnych spotkań pacjenta lub/i rodziny z psychologiem, lub w postaci zorganizowanej pracy grupowej. Wybór formy zawsze należy do pacjenta i bywa poprzedzony rozmową z psychologiem. Wstępna konsultacja ma na celu obustronne upewnienie się, czy wybrana przez pacjenta forma oddziaływania psychologicznego spełnia jego oczekiwania i potrzeby.

Koncepcja grupy psychoedukacyjnej charakteryzuje się pewnymi regułami. Ma określoną liczebność - zwykle od 6 do 12 osób; ramy czasowe - od 90 do 120 minut; plan zagadnień na 6-12 spotkań. Określona jest także jasno sama grupa uczestników, np. grupa dla osób po nawrocie choroby nowotworowej czy w trakcie leczenia. Podział wprowadzany jest z myślą o zoptymalizowaniu korzyści emocjonalnych i poznawczych. W grupie osób, które są w różnych fazach choroby i leczenia, byłoby zbyt wiele czynników, powodujących lęk i depresję. W grupie psychoedukacyjnej pacjenci dzielą się swymi doświadczeniami. Ma to walor wspierający. Taka forma pomocy bywa często uznawana w dużym stopniu za wiarygodną i przekonującą (Swaminath, 2009, s. 171-172).

\section{Założenia autorskiego programu edukacyjnego Akademii Walki z Rakiem}

Akademia Walki z Rakiem (AWzR) powstała w 2005 roku w Toruniu z inicjatywy Fundacji „Światło” jako odpowiedź na potrzeby pacjentów chorych onkologicznie oraz ich rodzin. W założeniu miała ona wypełnić istotną niszę na rynku świadczeń zdrowotnych, gdzie pacjent i jego bliscy częstokroć pozostawieni są sami sobie z własną wiedzą na temat choroby, lękiem co do dalszych rokowań. Obecnie, 12 filii w całej Polsce tworzy Ogólnopolską Sieć Akademii Walki z Rakiem. Rocznie w AWzR pomoc otrzymuje ponad 500 osób. Podopieczni akademii to osoby dorosłe, z różnymi typami choroby nowotworowej, będące na różnych jej etapach - od diagnozowania, poprzez leczenie, remisję czy wznowę choroby.

Dlaczego „Akademia”? Nazwa podkreśla, że jest to miejsce, gdzie osoby chore znajdą merytoryczną wiedzę na tematy związane z chorobą i jej wpływem na funkcjonowanie człowieka i jego bliskich. W AWzR pacjenci uczą się rozpoznawania w sobie sił wewnętrznych i zasobów do walki z chorobą. Jej celem jest również edukacja dotycząca konstruktywnej komunika- 
cji z otoczeniem społecznym, wyrażanie własnych potrzeb, a także umożliwienie spotkań z różnymi specjalistami - m.in. z dietetykiem, wizażystką, rehabilitantką, pracownikiem socjalnym, arteterapeutką (Kowalczyk, 2013, s. 11-20).

Edukacja terapeutyczna Akademii Walki z Rakiem oparta jest na koncepcji C. Simontona. W tej metodzie praca początkowo koncentruje się na redukcji lęku, tak aby pacjent odczuwał nadzieję i wytworzył pozytywne oczekiwania wobec życia, zdobyciu kontroli i możliwości wpływania na przebieg choroby. Pobudza to w pacjentach silną, rzeczywistą wolę życia, co przekłada się na wewnętrzną mobilizację zasobów oraz aktywne uczestnictwo w dążeniu do zdrowia. Praca z pacjentem przebiega w czterech etapach. Pierwszy z nich polega na zyskaniu nowej świadomości możliwości zmiany niekorzystnych, antyzdrowotnych zachowań. W drugim etapie, pacjent pracuje nad rozwiązaniem pojawiających się konfliktów i odreagowywaniem negatywnych emocji, co doprowadzić ma do zwiększenia energii psychicznej zaangażowanej dotychczas w podtrzymywanie zachowań antyzdrowotnych. Pokonanie lęku i początek przeżywania nadziei oraz rzeczywistej woli życia stanowi granicę przejścia do trzeciego etapu pracy. Pracując z pacjentem nad zmianą zachowań zdrowotnych, należy być szczególnie wrażliwym na indywidualną analizę ich dotychczasowego życia i czynników, które mogły być odpowiedzialne za rozwinięcie się choroby (Klatkiewicz A., 2008, s. 205-207).

Zajęcia w AWzR to cykl 30 dwugodzinnych spotkań, podzielonych na trzy etapy. Rekrutację do grupy poprzedzają indywidualne spotkania z prowadzącym zajęcia. Grupa nie powinna liczyć więcej niż 8 osób. Pacjenci po skończeniu trzech cykli spotkań mają możliwość uczestniczenia w grupach samopomocowych, które odbywają się cyklicznie, minimum raz w miesiącu. Pacjent może korzystać z oferty AWzR tak długo jak zechce. W oddziale toruńskim są osoby, które korzystają z różnych form edukacji, wsparcia już 12 lat.

W procesie edukacji realizowane są zagadnienia dotyczące m.in.: systemowej koncepcji zdrowia:

- przyczyn, przebiegu, rokowania w chorobie nowotworowej,

- związków między stresem a chorobą,

- psychosomatycznego modelu rozwoju nowotworu,

- racjonalnej terapii zachowań,

- relaksacji i wizualizacji,

- znaczenia diety i aktywności fizycznej w chorobie nowotworowej,

- radzenia sobie ze stresem, 
- komunikacji interpersonalnej.

Opracowany w Akademii Walki z Rakiem, autorski program edukacji pacjentów w chorobie nowotworowej obejmuje trzy bloki tematyczne:

- zajęcia z przekonaniami - RTZ - nurt terapii poznawczo-behawioralnej,

- radzenie sobie ze stresem, stratami/poszerzenie zasobów/praca $\mathrm{z}$ wyobraźnią,

- rozwijanie umiejętności troszczenia się o siebie/asertywność.

W ramach pierwszego bloku tematycznego realizowane są następujące tematy:

1. zaufanie i poczucie bezpieczeństwa (2 spotkania),

2. komunikacja w grupie, $\mathrm{w}$ rodzinie, $\mathrm{z}$ pracownikami służby zdrowia (2 spotkania),

3. praca z przekonaniami (RTZ) - przekonania dotyczące zdrowia, choroby, życia, rodziny, leczenia itd. (3 spotkania),

4. zdrowa semantyka (1 spotkanie),

5. strategie radzenia sobie w sytuacjach trudnych - analiza doświadczeń pacjentów (2 spotkanie).

Drugi blok tematyczny obejmuje:

1. stres; psychosomatyczny model powrotu do zdrowia (3 spotkania),

2. praca z zasobami, stosowanie technik sugestywnych, praca z wyobraźnią (2 spotkania),

3. uczucia, emocje - rozpoznawanie, sposoby okazywania, ekspresja emocji (3 spotkania),

4. umieranie, śmierć, życiowe straty (2 spotkania).

Ostatni blok tematyczny obejmuje następujące zagadnienia:

a) asertywność (2 spotkania),

b) ja w rodzinie, środowisku - komunikacja w rodzinie, funkcje i role, role utracone czasowo i na stałe, przyjęcie nowych ról, przekazy rodzinne (4 spotkania),

c) ja i moja choroba - co choroba mi dała, nowa tożsamość, plan zdrowienia, cele zdrowienia (4 spotkania).

Program AWzR jest analizowany w trakcie corocznych spotkań koordynatorów wszystkich polskich filii w kontekście najnowszych badań z dziedziny onkologii i psychoonkologii oraz dostosowywany do potrzeb pacjentów.

W realizowanych $\mathrm{w}$ AWzR zajęciach psychoedukacyjnych wykorzystywane są metody aktywizujące, których istotą jest przenoszenie akcentu z procesu nauczania na proces uczenia się; uwzględnianie emocjonalnego aspektu tego procesu; stwarzanie uczącym się przestrzeni do samodzielne- 
go myślenia i działania. Uczestnicy spotkań mogą więc podejmować decyzje dotyczące przebiegu, modyfikacji procesu uczenia się, wywierają aktywny wpływ na wszystko, co dzieje się w grupie, negocjują treści i formy uczenia się, zgłaszają własne potrzeby dotyczące wiedzy i umiejętności. Osoba prowadząca zajęcia jest zaś organizatorem procesu doświadczania, współplanującą z grupą jej aktywność i koordynującą realizację wspólnego planu działania.

Edukację terapeutyczną odbywającą się indywidualnie i w grupach uzupełniają organizowane raz w roku warsztaty intensywne, które są wyjazdowe i trwają trzy dni (Rębiałkowska-Stankiewicz, 2016, s. 217-232).

\section{Podsumowanie}

Edukacja terapeutyczna stanowi integralną część terapii w chorobie nowotworowej. Podobnie jak dieta czy rehabilitacja uzupełniają leczenie onkologiczne, tak psychoedukacja dopełnia proces leczenia w sferze medycznej, psychologicznej, społecznej. Jej skuteczność potwierdzają cytowane wcześniej badania naukowe oraz prowadzona w AWzR ewaluacja. W 2016 roku (na sześciopunktowej skali) pacjenci (189 osób) ocenili swoją wiedzę i umiejętności przed edukacją i po edukacji terapeutycznej. I tak, w punktach, ocena umiejętności radzenia sobie ze stresem wzrosła z 2,8 do 4,7; umiejętności komunikacyjne z 3,6 do 5,1; umiejętność rozpoznawania i mówienia o własnych emocjach z 3,3 do 4,8; znajomość zasad odżywiania się w chorobie z 3,8 do 5,4; dbałość o sprawność fizyczną z 2,7 do 4,4; znajomość praw pacjenta z 2,1 do 4,1 .

Jak widać, pozytywne oddziaływanie edukacji osób chorych uwidacznia się zarówno w sferze samopoczucia emocjonalnego, jak i w poziomie wiedzy dotyczącej zachowań zdrowotnych w chorobie. Warto zatem promować działania edukacyjne wśród wszystkich chorych, którzy są nimi zainteresowani i czują się gotowi, by pogłębić wiedzę o chorobie i o samych sobie. Dwunastoletnie doświadczenia Akademii Walki z Rakiem wskazują, że nie może się ograniczać tylko do wiadomości z zakresu medycyny. Silne emocje ulegają wyciszaniu dzięki temu, że pacjent zaczyna rozumieć to, co do tej pory było dla niego niezrozumiałe i niejasne. Edukacja terapeutyczna jest także sposobnością, by w bezpiecznych warunkach pacjenci doskonalili komunikację $z$ personelem medycznym, by mieli odwagę zadawać pytania istotne ze swego punktu widzenia. Zadając je w odpowiedniej formie mają szansę uzyskać wyczekiwane odpowiedzi. Istotną częścią psychoedukacji jest 
również udzielanie rzetelnych informacji w zakresie socjalno-prawnym i zawodowym (poradnictwo, dotyczące orzecznictwa rentowego, orzecznictwa o stopniu niepełnosprawności oraz zasiłków i świadczeń z pomocy społecznej). Warto również podkreślić, że pacjent uczestniczący w zajęciach grupy psychoedukacyjnej z osobami, dzielącymi zbliżone doświadczenia, rozwija więzi emocjonalne. Pogłębione relacje i zawarte przyjaźnie stanowią potencjał wiedzy, zaufania, akceptacji i wsparcia. Osoby, które zdobyły potrzebną wiedzę podczas spotkań psychoedukacyjnych, aktywniej uczestniczą w leczeniu. Ich poczucie wpływu na jakość życia wzrasta. Mówią zwykle o zwiększonej decyzyjności.

Akademia Walki z Rakiem jest jedyną w Polsce organizacją świadczącą tak wszechstronną, długoterminową i bezpłatną edukację terapeutyczną dla osób zmagających się z rakiem. W świetle wciąż wzrastającej liczby osób chorych onkologicznie oraz dłuższej przeżywalności pacjentów, tego typu działania stają się koniecznością oraz obowiązkiem w zakresie zdrowia publicznego.

\section{Bibliografia}

Charońska E. (1997), Zarys wybranych problemów edukacji zdrowotnej, Centrum Edukacji Medycznej, Warszawa.

Colom F. (2010), Keeping therapies simple: psychoeducation in the prevention of relapse in affective disorders. „Br J Psychiatry”, May, 1985, s. 338-340.

Cylkowska-Nowak M. (2008), Między promocja zdrowia, profilaktykq a terapiq - zasadnicze podejścia edukacji na rzecz zdrowia, [w:] Cylkowska- Nowak M. (red.), Edukacja zdrowotna. Możiiwości, problemy, ograniczenia, Wydawnictwo Naukowe Uniwersytetu Medycznego im. Karola Marcinkowskiego, Poznań.

De Walden-Gałuszko K. (2013), Tarcza woli życia, [w:] Pająk P. (red.), Siły, które pokonaja raka. Psychologiczne terapie wspomagajace w chorobie nowotworowej, $\mathrm{Wy}-$ dawnictwo Charaktery, Kielce, s. 23-30.

Hejwosz D.A. (2008). Edukacja pacjentów a edukacja studentów. Próba zróżnicowania, [w:] Cylkowska-Nowak M. (red.), Edukacja zdrowotna. Możliwości, problemy, ograniczenia, Wydawnictwo Naukowe Uniwersytetu Medycznego im. Karola Marcinkowskiego, Poznań.

Heszen-Niejodek I. (1991), Radzenie sobie z konfrontacją stresowq, „Nowiny Psychologiczne", nr 1-2.

Hundertmark-Mayser J., (2004), Selbstihilfe braucht verlassliche Strukturen, „Das AOK-Forum fur Politik, Praxis und Wissenschaft Special", 4(6).

Klatkiewicz A. (2007), Kryzys choroby czy szansa na zmianę swojego życia? Czynniki wptywające na postrzeganie i wykorzystanie sytuacji choroby jako możliwości 
zmiany swojego życia, [w:] Janowski K., Artymiak M. (red.), Człowiek chory. Aspekty biopsychospołeczne, Wydawnictwo BEST PRINT, Lublin, s. 205-207.

Klatkiewicz A. (2008), Gotowość uczenia się zachowań zdrowotnych w sytuacji choroby, [w:] Cylkowska-Nowak M. (red.), Edukacja zdrowotna. Możliwości, problemy, ograniczenia, Wydawnictwo Naukowe Uniwersytetu Medycznego im. Karola Marcinkowskiego, Poznań.

Kowalczyk M. (2013), Ogólnopolska Sieć Akademii Walki z Rakiem - powstanie, cele i działanie, [w:] Rębiałkowska-Stankiewicz M., Kowalczyk M., Akademia Walki z Rakiem - wsparcie społeczne, Wydawnictwo Adam Marszałek, Torun.

Laff H. (2004), Die Hilfe kommt an, „Das AOK-Forum für Politik, Praxis und Wissenschaft Special", 4(8).

Mehl U. (2011), Grupy psychoedukacyjne, [w:] Dorfmüller M., Dietzfelbinger H. (red.), Psychoonkologia. Diagnostyka - metody terapeutyczne, Wydawnictwo Elsevier Urban \& Partner, Wrocław.

Pouget-Schors D. (2011), Diagnostyka psychoonkologiczna, [w:] Dorfmüller M., Dietzfelbinger H. (red.), Psychoonkologia. Diagnostyka - metody terapeutyczne, Wydawnictwo Elsevier Urban \& Partner, Wrocław.

Rębiałkowska-Stankiewicz M. (2016), Wykorzystanie edukacji przygoda $w$ radzeniu sobie ze stresem choroby nowotworowej, „Kwartalnik Pedagogiczny”, 61(2), s. 217-232.

Rogiewicz M., Lutostańska M. (2013), Psychospołeczne problemy osób chorych onkologicznie, [w:] Rębiałkowska-Stankiewicz M., Kowalczyk M. (red.), Akademia Walki z Rakiem - wsparcie społeczne, Wydawnictwo Adam Marszałek, Toruń, s. 24-52.

Swaminath G. (2009), Psychoeducation. „Indian J Psychiatry”, 51(3), s. 171-172.

Woynarowska B. (2007), Edukacja zdrowotna, Wydawnictwo Naukowe PWN, Warszawa.

Zalewska-Meler A. (2009), (Nie)obecne kategorie w obszarze zdrowia człowieka, Oficyna Wydawnicza Impuls, Kraków. 